\title{
Ferrous iron oxidation by anoxygenic phototrophic bacteria
}

\author{
Friedrich Widdel*, Sylvia Schnell†, Silke Heising $\dagger$, \\ Armin Ehrenreich*, Bernhard Assmus* \\ \& Bernhard Schink $\uparrow$ \\ * Max-Planck-Institut für Marine Mikrobiologie, Fahrenheitstrasse 1, \\ D-2800 Bremen, Germany \\ † Fakultät für Biologie der Universität Konstanz, Postfach 5560 , \\ D-7750 Konstanz, Germany
}

\begin{abstract}
NATURAL oxidation of ferrous to ferric iron by bacteria such as Thiobacillus ferrooxidans or Gallionella ferruginea ${ }^{1}$, or by chemical oxidation $^{2,3}$ has previously been thought always to involve molecular oxygen as the electron acceptor. Anoxic photochemical reactions ${ }^{4-6}$ or a photobiological process involving two photosystems ${ }^{7-9}$ have also been discussed as mechanisms of ferrous iron oxidation. The knowledge of such processes has implications that bear on our understanding of the origin of Precambrian banded iron formations ${ }^{10-14}$. The reducing power of ferrous iron increases dramatically at $\mathrm{pH}$ values higher than $2-3$ owing to the formation of ferric hydroxy and oxyhydroxy compounds ${ }^{1,2,15}$ (Fig. 1). The standard redox potential of $\mathrm{Fe}^{3+} / \mathrm{Fe}^{2+}\left(E_{0}=+0.77 \mathrm{~V}\right)$ is relevant only under acidic conditions. At pH 7.0, the couples $\mathrm{Fe}(\mathrm{OH})_{3} / \mathrm{Fe}^{2+}$ $\left(E_{0}^{\prime}=-0.236 \mathrm{~V}\right)$ or $\mathrm{Fe}(\mathrm{OH})_{3}+\mathrm{HCO}_{3}^{-} / \mathrm{FeCO}_{3}\left(E_{0}^{\prime}=+\mathbf{0 . 2 0 0} \mathrm{V}\right)$ prevail, matching redox potentials measured in natural sediments ${ }^{9,16,17}$. It should thus be possible for $\mathrm{Fe}(11)$ around $\mathrm{pH} 7.0$ to function as an electron donor for anoxygenic photosynthesis. The midpoint potential of the reaction centre in purple bacteria is around $+0.45 \mathrm{~V}$ (ref. 18). Here we describe purple, non-sulphur bacteria that can indeed oxidize colourless Fe(II) to brown Fe(III) and reduce $\mathrm{CO}_{2}$ to cell material, implying that oxygen-independent biological iron oxidation was possible before the evolution of oxygenic photosynthesis.

Samples of black, reduced sediment stored anoxically in the light had rusty depositions on the glass wall after four weeks without showing development of algae or cyanobacteria. To study this phenomenon in more detail, enrichment cultures were
\end{abstract}

To whom correspondence should be addressed. 
set up under nitrogen gas in butyl rubber-sealed glass bottles with strictly anoxic, bicarbonate-buffered $(20 \mathrm{mM})$ mineral medium $^{19}$, pH 7.0, free of sulphide, but containing vitamins and trace elements ${ }^{20}$. Depending on the inoculum source, either freshwater medium or saltwater medium (with $20.0 \mathrm{~g} \mathrm{NaCl}$ and $3.0 \mathrm{~g} \mathrm{MgCl}_{2} .6 \mathrm{H}_{2} \mathrm{O}$ per litre) was used. $\mathrm{FeSO}_{4}$ was added as the sole reductant to the medium to obtain a concentration of 2 or $10 \mathrm{mM}$, from an anoxic stock solution kept under nitrogen gas. The $\mathrm{Fe}^{2+}$ ions reacted, probably with carbonate and phosphate in the medium, to form a fluffy, white precipitate. Cultures were inoculated with few drops of water from the sediment surface of freshwater ponds or from the Jadebusen, North Sea.

After 2-8 weeks of incubation at low light intensity $(25 \mathrm{~W}$ light bulb, 30-40 cm distance) with or without a long-wavelength $(>780 \mathrm{~nm})$ light filter, the precipitate in the bottles turned greenish-grey and then rusty-brown at the sites of highest light intensity. This material consisted of $\mathrm{Fe}$ (III) oxides containing embedded cells which did not exhibit fluorescence when checked at $436-520 \mathrm{~nm}$ excitation wavelength, indicating the absence of chlorophyll $a$. In a control experiment, the light-dependent oxidation of ferrous iron was not inhibited by addition of $100 \mu \mathrm{M}$ dichlorophenyldimethylurea which at this concentration is more than sufficient to inhibit photosystem II (ref. 21). After three subcultures, the bacteria were purified in agar dilutions ${ }^{19}$.

Three major morphological types were isolated from freshwater sources. One of these, after growth with succinate or acetate, resembled Rhodomicrobium vannielii (Fig. 2a) and exhibited a cell cycle typical of this species. After growth with ferrous iron, the cells were covered with highly refractile crusts of $\mathrm{Fe}(\mathrm{III})$ precipitates (Fig. $2 b$ ). The second type had ovoid to rod-shaped cells similar to Rhodopseudomonas palustris. The third cell type contained gas vesicles and morphologically resembled Thiodictyon spp., but did not grow with sulphide. These cells were less closely associated with the precipitate (Fig. 2c). Authenticated Thiodictyon species ${ }^{22}$ were also tested; however, they did not oxidize ferrous iron. The strains isolated from a marine enrichment culture grow poorly in the iron medium.

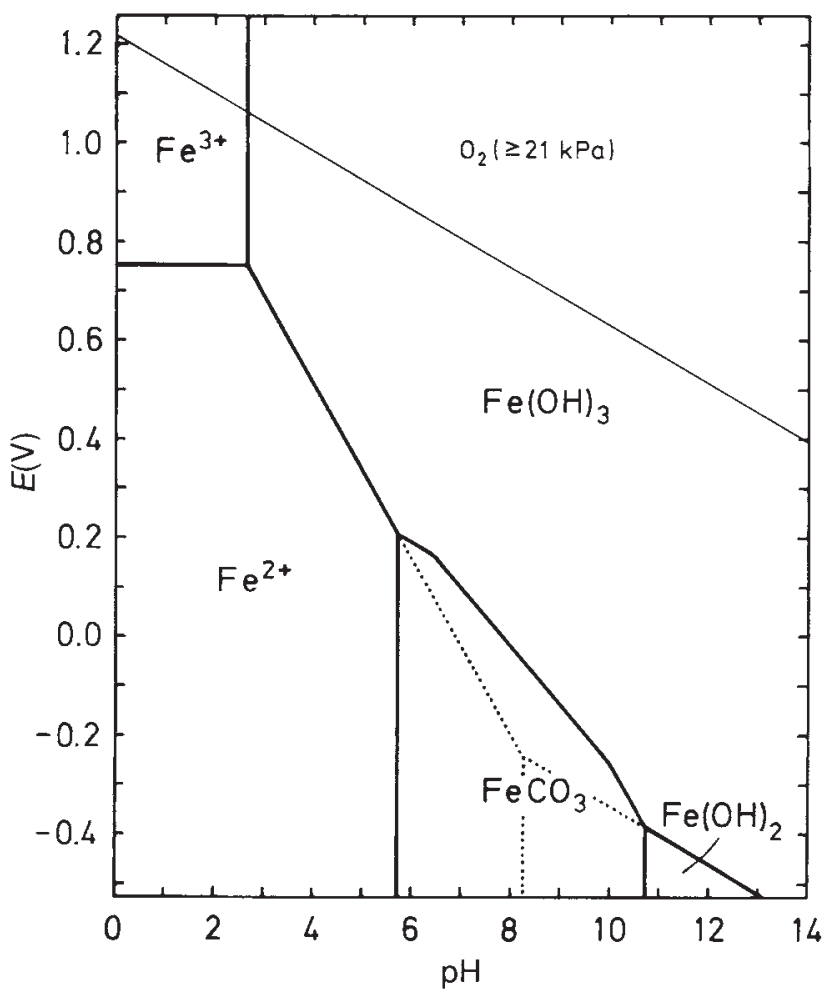

TABLE 1 Quantification of anaerobic phototrophic ferrous iron oxidation by purple bacteria

\begin{tabular}{ccc} 
& $\begin{array}{c}\text { Rhodomicrobium- } \\
\text { like isolate }\end{array}$ & $\begin{array}{c}\text { Gas vesicle- } \\
\text { containing } \\
\text { isolate }\end{array}$ \\
Fe(II) at the beginning & 1.94 & 10.0 \\
(mmol I $)^{*}$ & 0.77 & 0.5 \\
Fe(II) at the end $\left(\mathrm{mmol} \mathrm{I}^{-1}\right)^{*}$ & 1.17 & 9.5 \\
Fe(II) oxidized (mmol I $\left.{ }^{-1}\right)$ & 5.2 & 72 \\
Cell mass produced $\left(\mathrm{mg} \mathrm{I}^{-1}\right)$ & & \\
Theoretical cell mass & & 71 \\
production (mg I $\left.{ }^{-1}\right)$ & 8.8 & 57 \\
from equation (1) & 7.0 & \\
from equation (2) & & \\
\hline
\end{tabular}

Cultures were incubated for 4 weeks or 12 days, respectively.

* Fe(tl) was determined photometrically ${ }^{25}$ after dissolution of the total precipitate of a culture in $2 \mathrm{M} \mathrm{HCl}, \mathrm{Fe}(\| \mathrm{f})$ by the same method after reduction with hydroxylamine ${ }^{26}$

† Cell mass was determined by protein. Protein was centrifuged from the $\mathrm{HCl}$-treated culture after addition of $0.6 \mathrm{M}$ (final concentration) trichloroacetic acid, dissolved in $0.1 \mathrm{M} \mathrm{NaOH}$ and determined with the biuret reagent ${ }^{27}$. The cell mass/protein ratio was measured in a separate experiment with cells grown on acetate and then dried to constant weight at $70^{\circ} \mathrm{C}$.

$\ddagger$ Theoretical cell mass production (approximate formula, $\mathrm{CH}_{2} \mathrm{O}$ or $\mathrm{C}_{4} \mathrm{H}_{7} \mathrm{O}_{2} \mathrm{~N}$ ) with ferrous iron as electron donor was calculated by the following equations:

$$
\begin{gathered}
4 \mathrm{FeCO}_{3}+7 \mathrm{H}_{2} \mathrm{O} \rightarrow\left(\mathrm{CH}_{2} \mathrm{O}\right)+4 \mathrm{Fe}(\mathrm{OH})_{3}+3 \mathrm{CO}_{2} \\
17 \mathrm{FeCO}_{3}+28 \mathrm{H}_{2} \mathrm{O}+\mathrm{NH}_{4}^{+} \rightarrow\left(\mathrm{C}_{4} \mathrm{H}_{8} \mathrm{O}_{2} \mathrm{~N}\right)+17 \mathrm{Fe}(\mathrm{OH})_{3}+13 \mathrm{CO}_{2}+\mathrm{H}^{+}
\end{gathered}
$$

Thus, $1 \mathrm{mmol} \mathrm{Fe}(\mathrm{II})$ theoretically yields 7.51 or $6.01 \mathrm{mg}$ cell mass, respectively

The measured electron balance of iron oxidation versus $\mathrm{CO}_{2}$ dependent cell mass formation by the freshwater isolate came close to the theoretically expected values (Table 1). No iron oxidation occurred in the dark or in a sterile control experiment: the precipitate remained colourless and the ferrous iron content
FIG. 1 Graph of $E$ versus $\mathrm{pH}$ for iron species and $\mathrm{O}_{2}$ at atmospheric concentration $\left(\mathrm{H}_{2} \mathrm{O}\right.$ below respective line) at $25^{\circ} \mathrm{C}$. The calculations are based on concentrations of $1 \times 10^{-3} \mathrm{moll}^{-1}$ total iron, $2 \times 10^{-2} \mathrm{moll}^{-1}$ dissolved inorganic carbon $\left(\mathrm{CO}_{2}+\mathrm{HCO}_{3}^{-}+\mathrm{CO}_{3}^{2-}\right)$, and non-reacting ions to make up an ionic strength of 0.05 ; the individual (calculated) activity coefficients of $\mathrm{Fe}^{3+}, \mathrm{Fe}^{2+}$ and $\mathrm{HCO}_{3}^{-}$are $0.24,0.48$ and 0.81 , respectively ${ }^{2}$. Of various solubility products given for $\mathrm{Fe}(\mathrm{OH})_{3}$, a value of $10^{-38}$ was taken which refers to a fresh precipitate ${ }^{2}$. On a line demarcating $\mathrm{Fe}^{2+}$ or $\mathrm{Fe}^{3+}$, the respective ion accounts for $50 \%\left(=0.5 \times 10^{-3} \mathrm{moll}^{-1}\right)$ of the total iron. Dotted lines indicate the extended stability regions of $\mathrm{Fe}^{2+}$ and $\mathrm{Fe}(\mathrm{OH})_{2}$ in the absence of inorganic carbon. For easy overview, $\mathrm{H}_{2}(\mathrm{OV}$ at $\mathrm{pHO},-0.414 \mathrm{~V}$ at $\mathrm{pH} 7$; at $101 \mathrm{kPa}$ ), magnetite and $\mathrm{Fe}(\mathrm{OH})^{2+}$ are not included; hence, the iron species indicated are metastable in certain regions. Metallic iron (below $-0.547 \mathrm{~V}$ ) is outside the panel. Other details and overviews are given in the literature $\mathrm{e}^{15}$ 


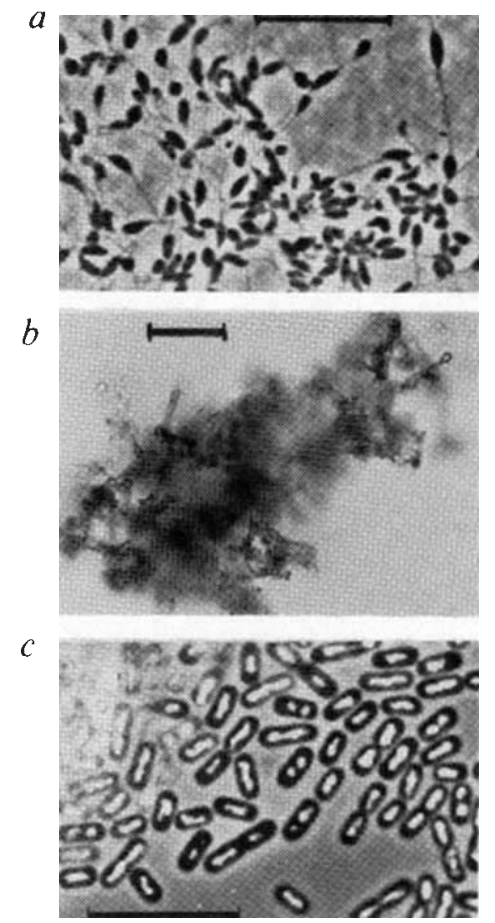

FIG. 2 Phase contrast photomicrographs of iron-oxidizing phototrophic bac teria. $a$, Rhodomicrobium-like isolate grown with succinate; $b$, Rhodomicrobium-like isolate grown with ferrous iron; $c$, gas vesicle-containing freshwater isolate grown with ferrous iron. Scale bars, $10 \mu \mathrm{m}$.

did not change. No growth occurred in media without iron added.

These results show that ferrous iron oxidation requires only photosystem I in anoxygenic phototrophs, and that anaerobic ferrous iron oxidation was therefore possible before the evolution of oxygenic two-step photosynthesis. These findings, together with the recently discussed photochemical ferrous iron oxidation ${ }^{4-6}$, again question the assumption that the appearance of $\mathrm{Fe}(\mathrm{III})$ oxides in banded iron formations is always an indicator of the appearance of free oxygen. Anoxygenic phototrophic bacteria as isolated in the present study may have contributed to early banded iron formation at Archaean times before oxygen became significant as an oxidant. Such bacteria may still be of ecological significance as a means of regeneration of a widespread oxidant ${ }^{23,24}$ in anoxic low-sulphur littoral sediments.

Received 20 July 1992; accepted 17 February 1993

1. Wood, P. M. in Bacterial Energy Transouction (ed. Anthony, C.) 183-230 (Academic, London, 1988)

2. Stumm, W. \& Morgan, J. J. Aquatic Chemistry 2nd ed (Wiley-Interscience, New York, 1981)

3. Schwertmann, U. \& Cornell, R. M. Iron Oxides in the Laboratory (VCH. Weinheim. 1991).

4. Cairns-Smith, A. G. Nature 276, 807-808 (1978).

5. Braterman, P. S., Cairns-Smith, A. G. \& Sloper, R. W. Nature 303, 163-164 (1983).

6. François, L. M. Nature $\mathbf{3 2 0}, 352.354$ (1986). 449-453 (Liss, New York, 1984).

8. Walker, J. C. G. Nature 329, 710-711 (1987).

9. Cohen, Y in Microbial Mats (eds Cohen, Y. \& Rosenberg, E) 22-36 (Am. Soc. Microbiol., Washington, 1990)

10. Schopf. J. W. A. Rev. Earth Planet. Sci. 3, 213-249 (1975)

11. Schidlowski, M. in The Early History of the Earth (ed. Windley, B. F.) 525-535 (Wiley, London, 1976).

12. Gole, M. J. \& Klein, C. J. Geol. 89, 169-183 (1981)

13. Beukes, N. J. \& Klein, C. in The Proterozoic Biosphere (eds Schopf. J. W. \& Klein, C.) 147-158 (Cambridge Univ. Press, Cambridge, 1992).

14. Kasting, J. F., Holland, H. D. \& Kump, L. R. in The Proterozoic Biosphere (eds Schopf, J. W. \& Klein, C.) 159-163 (Cambridge Univ. Press, Cambridge. 1992)

15. Garrels, R. M. \& Christ, C. L. Solutions, Minerals and Equilibria (Harper \& Row. New York, 1965). 16. Mackenzie, F. T. \& Wollast, R. in Global Chemical Cycles and their Alterations by Man (ed. Stumm. W.) 45-59 (Dahlem Konferenzen, Berlin, 1977).

17. Jørgensen, B. B. in Microbial Geochemistry (ed. Krumbein, W. E.) 91-124 (Blackwell, Oxford, 1983)

18. Dutton, P. L. \& Prince, R. C. in The Photosynthetic Bacteria (eds Clayton, R. K. \& Sistrom, W. R.) 525-570 (Plenum, New York, 1978)
19. Widdel, F. \& Bak. F. in The Prokaryotes Vol. 4 (eds Balows, A., Trüper, H. G., Dworkin. M., Harder W. \& Schleifer, K.-H.) 3352-3378 (Springer, New York, 1992)

20. Pfennig, N. Int. J. syst. Bact. 28, 283-288 (1978).

21. Cohen, Y., Jørgensen, B. B., Revsbech, N. P.\& Poplawski, R. Appl. environ. Microbiol 51, 398-407 (1986).

22. Pfernig, N in Bergey's Manual of Systematic Bacteriology Vol 3 (eds Staley, J. T. Bryant. M. P.

Pfennig, N. \& Holt, J. G.) 1650-1651 (Williams \& Wilkins, Baltimore, 1989)

23. Lovley. D. R. Microbiol. Rev. 55, 259-287 (1991)

24. Nealson. K. H. \& Myers, C. R. Appl. environ. Microbiol, 58, 439-443 (1992

25. Stookey, L. L. Analyt. Chem. 42, 779-781 (1970).

26. Lovley, D. R. \& Philipps, E. J. P. Appl. environ. Microbiol 51, 683-689 (1986)

27. Lowry, O. H., Rosebrough, N. J., Farr, A. L. \& Randall, R. J. J. biol. Chem. 193, 265-275 (1951)

\section{Kinship affects morphogenesis in cannibalistic salamanders}

\author{
David W. Pfennig* \& James P. Collins $\dagger$ \\ * Section of Neurobiology and Behavior, Mudd Hall, Cornell University, \\ Ithaca, New York 14853, USA \\ + Department of Zoology, Arizona State University, Tempe \\ Arizona 85287, USA
}

INCLUSIVE fitness theory predicts that organisms can often increase their fitness by helping relatives ${ }^{1}$. Indeed, many animals modify their behaviour towards kin in a fashion consistent with theory ${ }^{2-4}$. Morphogenesis may also be sensitive to kinship environment, especially in species that facultatively produce distinct morphs that differ in their ability to harm relatives, such as those that produce alternative cannibalistic and non-cannibalistic phenotypes $^{5-9}$. We tested this hypothesis by examining whether consanguinity affected the probability that structurally distinctive cannibal morphs ${ }^{5,10}$ would develop in larval Arizona tiger salamanders (Ambystoma tigrinum nebulosum). We report here that when tiger salamander larvae are reared in mixed-brood groups they are significantly more likely to develop the cannibal morphology and at an earlier age than siblings reared in pure-sibship groups. In general, morphogenesis may be responsive to kinship in any species that facultatively develops structures that can be used against conspecifics as weaponry.

Tiger salamander larvae occur in nature as two alternative morphotypes ${ }^{5,10}$ : a 'typical' morph that feeds mostly on invertebrate prey, and a larger, physically distinctive 'cannibal' morph that has specialized oral structures to facilitate the ingestion of conspecifics ${ }^{10-12}$. Cannibals are induced facultatively by high densities of conspecifics ${ }^{13,14}$.

The potential exists in nature for cannibal-morph larvae to eat relatives. Stomach content analyses of wild-caught cannibals indicate that they often consume conspecifics of their own size and smaller ${ }^{11,15}$. The occurrence of these two environmentally induced morphs enabled us to test whether kinship influences morphogenesis of alternative morphs that differ in their ability to harm relatives.

We randomly assigned similarly sized, two-week-old larvae from eight different sibships (three of which were cousins) to three different treatment categories: larvae were reared in groups of 16 with (1) siblings only, (2) equal numbers of siblings and nonsiblings (some were cousins, others were non-kin), or (3) one sibling and two larvae from each of the seven other sibships (Fig. 1). This manipulation mimicked a natural situation. Larvae are surrounded solely or primarily by siblings in ponds in which only a few females oviposit, whereas larvae are surrounded primarily by non-relatives in ponds where numerous females oviposit (unpublished observation). Inclusive fitness theory predicts that larvae in the former setting should be less likely than those in the latter setting to develop into cannibals.

Cannibal morphs were indeed significantly more likely to develop in mixed-brood groups than in pure-sibship groups (Table 1). No more than one cannibal was produced per aquarium. In aquaria containing relatively few larvae, cannibals 